\title{
Evaluation of Land Use Suitabililty Based on Land Capability in Mojokerto Regency
}

\author{
Zuhri Firdaus ${ }^{1}$, Sudarto ${ }^{2}$, Soemarno ${ }^{2}$ \\ 1Post Graduate School of Environmental and Development, Graduate Progam, University of Brawijaya, Malang, \\ Indonesia \\ ${ }^{2}$ Soil Department, Faculty of Agriculture, University of Brawijaya, Malang, Indonesia
}

Abstract

Evaluation of the environmental carrying capacity should be measured as part of sustainable land use planning. One of methods to evaluate this carrying capacity is land capability evaluation.. This study aims to evaluate the suitability of landuse in each of land capability classes in Mojokerto Regency. Land capability is obtained by spatial analysis and overlay of several criteria for land capability, included soil texture, effective soil depth, drainage, land slope, and soil erosion. The description of actual landuse is obtained using landsat $8 \mathrm{OLI}$ images at coverage time in May 2018. The results of study show that the land capability in Mojokerto Regency varies from Class I to Class VIII. The actual land use in Mojokerto Regency are about $98 \%$ or $95314.33 \mathrm{Ha}$ are suitable to the land capability, and $2 \%$ or of $2078.67 \mathrm{Ha}$ are unsuitable to the land capability. Based on the environmental carrying capacity, about $78.85 \%$ or 76798.89 Ha of land in Mojokerto Regency are allocated accordingly, and $0.90 \%$ or of $875.29 \mathrm{Ha}$ of land are allocated beyond their carrying capacity, $19.39 \%$ or $18884.18 \mathrm{Ha}$ of land are allocated in a conditional manner so it needs any specific treatments of landuse.

Keywords: Actual land use, Land capability, Sustainable

\section{INTRODUCTION}

Increasing population growth and the growing needs of the people in Indonesia have logical consequences for increasing land requirements [1][2]. The pattern of national development shows changes in land use planning which causes a reduction in the area of open spaces or green land cover. The uncontrolled land conversion beyond their carrying capacity can threaten sustainability of natural environment, agriculture production, food security and cause socio-economic losses [3];[4]; [5];[6];[7]; 8];[9].

Since Mojokerto Regency was established as one of the Megapolitan areas in East Java Province, its development has experienced rapid development, especially in the industrial and infrastructure sectors. This was indicated during 2013-2017 there has been a land conversion and change in land use [10]. The protection forests, production forests, plantation forests and perenniel crop gardens have reduced, while the land development for industries locations and human settlements have increased significantly

Correspondence address:

Zuhri Firdaus

Email : napierbudiman@gmail.com

Alamat : Post Graduate School of Environmental and Development, Graduate Progam, University of Brawijaya, Malang, Indonesia
$[11 ;[12] ;[13] ;[14] ;[15]$. The development of the region, landuse planning and residential planning is needed with an assessment of land carrying capacity [16];[17];[18], so that economics development are in accordance with the carrying capacity and capability of land [19];[20];[21]; [22].

Sustainable land management in an area is important, one of which is to determine the land capability class as a reference to determine the suitability of existing land use and the landuse plan in the spatial planning. Land capability evaluation aims to identify criteria for environmental limitations in the efforts of sustainable land use planning [23];[24]; [25]; [26]. The classification of land capability is a scientific activity to assess the physical characteristics of land, soil quality, land management and farming activities [27];[28]; [29];[30];[31];[32].

One of the tools used for the process of evaluating the suitability of land-based land use is the Geographic Information System (GIS) [33];[34];[35]. GIS applications play a role both in spatial analysis of land in a region and help to categorize spatial data based on potential and inhibiting factors in land use so that it effectively and efficiently facilitates mapping land capability classes [36]. Furthermore GIS methods can also be used in the assessment of land designation 
planned in the future for sustainable regional development [37];[38].

This study aims to evaluate the carrying capacity of the environment based on the suitability of the land capability class with actual land use and land allocation in the Mojokerto Regency Spatial Plan, East Java Province. The output of this study is in the form of recommendations on the use of space in accordance with the allotment of land carrying capacity.

\section{MATERIALS AND METHOD}

The study was conducted in Mojokerto Regency, East Java Province. This region is geographically located at $111^{\circ} 40^{\prime} 47$ "East Longitude and $7^{\circ} 18^{\prime} 35^{\prime \prime}$ to $7^{\circ} 47^{\prime} 30$ "South Latitude, with an area of $97393 \mathrm{Ha}$.

Description of actual land use and cover in Mojokerto Regency using 8 OLI TIRS recording images in May 2018. The process of classification of image interpretation uses the supervised classification with the help of ArcGis software. Analysis of types of land use are grouped into: (1) Settlements; (2) Fields; (3) Rice fields; (4) Industry; (5) Plantation; (6) Production Forests; (7) Protection Forests; (8) Forest Park; and (9) Water Bodies.

Analysis of land capability in this study uses a method adapted to the description by Arsyad (2010). In this study the basic data needed to create the capability land is a shapefile of soil types in Mojokerto Regency with a scale of 1 : 50.000 which was obtained from the Indonesian Center for Agricultural Land Resources Research and Development. Mojokerto Regency has 7 Soil Orders, namely Gleisol, Grumosol, Kambisol, Mediteran, Podsolik, Litosol dan Nitosol. The distribution of soil types is shown in Figure 1.

Classification of land capability classes is based on the intensity of limiting factors including: soil texture, effective depth, surface slope, drainage, and erosion rate. The reference criteria used in the classification are presented in Table 1. While the allowed land use in each land capability class based on Fenton's reference [39] is presented in Table 2.

The results of the analysis of land capability class are a reference in the evaluation process and then matched to the actual land use map of the interpretation of Lansat $8 \mathrm{OLI}$ images and maps of land space patterns in the Mojokerto Regency Spatial Plan (MRSP) using Overlay techniques.

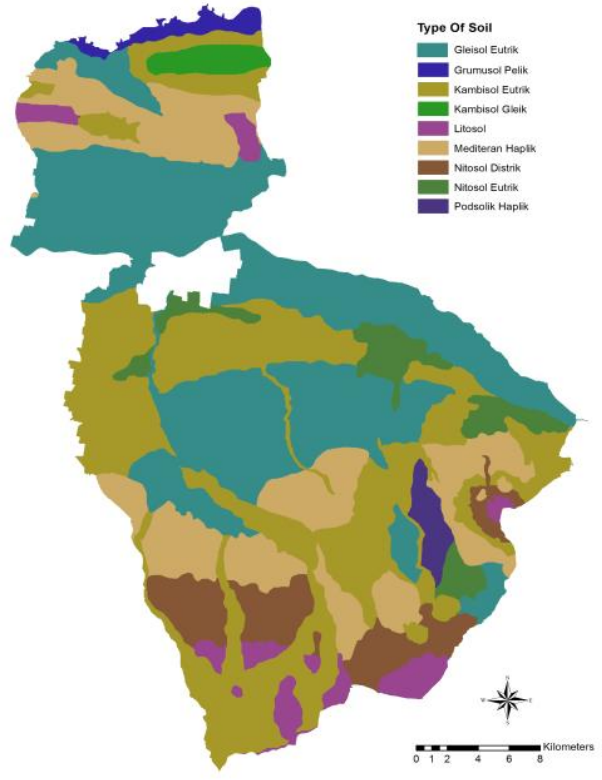

Figure 1. Soil Types in Mojokerto Regency

Suitability between land capability classes with actual land use and land allocation in the spatial pattern is classified into 3 (three) categories: (1) appropriate, if the actual land use or land allocation in the MRSP is in accordance with the capability of the land; (2) conditional appropriate, if the actual land use or land allocation in the RTRW (Spatial Plan) exceeds the capacity of the land, the use of the land is still possible, provided that it is given certain treatment to reduce or eliminate the limiting/inhibiting factors on land capability; while(3) it is not appropriate, meaning the actual land use or land allocation in the RTRW has exceeded the capacity-based carrying capacity of the land. In this evaluation process, the water body is not assessed accordingly.

\section{RESULTS AND DISCUSSION \\ Classification of Land Capability}

Mojokerto Regency has land capability classes that vary from class I to class VIII. The results of the analysis of the assessment of grouping of land capability classes are presented in Table 3 and the spatial distribution is shown in Figure 2.

Land class I in Mojokerto Regency is the best land without any boundaries which occupies an area of $13621.22 \mathrm{Ha}$ or $13.99 \%$, spread almost all of Trowulan, Sooko, Bangsal, Puri Districts and a small portion of Pungging, Pacet, Trawas, Kutorejo, Mojosari and Mojoanyar. 
Table 1. Limiting Factors in Each of Land Capability Classes

\begin{tabular}{|c|c|c|c|c|c|c|c|c|c|}
\hline \multirow[t]{2}{*}{ No. } & \multirow[t]{2}{*}{ Limiting Factors } & \multicolumn{8}{|c|}{ Land Capability Class } \\
\hline & & I & II & III & IV & V & $\mathrm{VI}$ & VII & VIII \\
\hline \multirow[t]{3}{*}{1.} & Texture & & & & & & & & \\
\hline & Upper layer & $t_{2} / t_{3}$ & $\mathrm{t}_{1} / \mathrm{t}_{4}$ & $t_{1} / t_{4}$ & $(*)$ & $(*)$ & $(*)$ & $(*)$ & $t_{5}$ \\
\hline & Bottom layer & $t_{2} / t_{3}$ & $\mathrm{t}_{1} / \mathrm{t}_{4}$ & $\mathrm{t}_{1} / \mathrm{t}_{4}$ & $(*)$ & $(*)$ & $(*)$ & $(*)$ & $t_{5}$ \\
\hline 2. & Slope & $\mathrm{s}_{0}$ & $\mathrm{~s}_{1}$ & $\mathrm{~s}_{2}$ & $\mathrm{~S}_{3}$ & $(*)$ & $\mathrm{S}_{4}$ & $\mathrm{~S}_{5}$ & $\mathrm{~s}_{6}$ \\
\hline 3. & Drainage & $\mathrm{d}_{0} / \mathrm{d}_{1}$ & $d_{2}$ & $d_{3}$ & $\mathrm{~d}_{4}$ & $(* *)$ & $(*)$ & $(*)$ & $(*)$ \\
\hline 4. & Effective Depth & $\mathrm{ed}_{0}$ & $\mathrm{ed}_{0}$ & $\mathrm{ed}_{1}$ & $\mathrm{ed}_{2}$ & $(*)$ & $\mathrm{ed}_{3}$ & $(*)$ & $(*)$ \\
\hline 5. & Erosion Rate & $e_{0}$ & $e_{1}$ & $e_{1}$ & $e_{2}$ & $(*)$ & $e_{3}$ & $\mathrm{e}_{4}$ & $(*)$ \\
\hline
\end{tabular}

Explanation: $(*)$ : It can have a lower distribution of the inhibiting factors of the land class;

$(* *)$ : the surface of the land is always flooded;

Texture: $\mathrm{t}_{1}$ : smooth; $\mathrm{t}_{2}$ : rather smooth; $\mathrm{t}_{3}$ : medium; $\mathrm{t}_{4}$ : rather rough: $\mathrm{t}_{5}$ : rough;

Slope: so (0-3\%; s $s_{1}(3-8 \%) ; s_{2}$ (8-15\%); s3 (15-30\%); s $s_{4}(30-45 \%)$; s $s_{5}(45-65 \%)$; s6 $(>65 \%)$;

Drainase: $d_{0}$ (good): $d_{1}$ (rather good); $d_{2}$ (rather bad); $d_{3}$ (bad); $d_{4}$ (very bad);

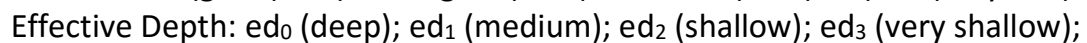

Erosi: $e_{0}$ (no erosion); $e_{1}$ (mild); $e_{2}$ (medium); $e_{3}$ (heavy); $e_{4}$ (very heavy).

Table 2. The Allowed Land Use in Each of Land Capability Class

\begin{tabular}{lll}
\hline No. & Land Capability Class & Allowed Land Use \\
\hline 1. & I & All types of land use \\
2. & II & All types of land use except Psi \\
3. & III & All types of land use kecuali Ag-vi and Ag-i (only Ag-m) \\
4. & IV & Ag-l, All types of grazing, All types of forests \\
5. & V & All types of grazing (Gi, Gm, GI), All types of forests \\
6. & VI & Gm, Gl, All types of forests \\
7. & VII & Gl, forests \\
8. & VIII & Nature preserve and Protected Forests \\
\hline
\end{tabular}

Source: Fenton (2014)

Explanation: $\mathrm{Ag}$-vi: very intensive agriculture; $\mathrm{Ag}$-i: intensive agriculture; $\mathrm{Ag}-\mathrm{m}$ : medium intensity agriculture; Ag-I: limited agriculture; Gi: intensive grazing; Gm: medium grazing; GI: limited grazing.

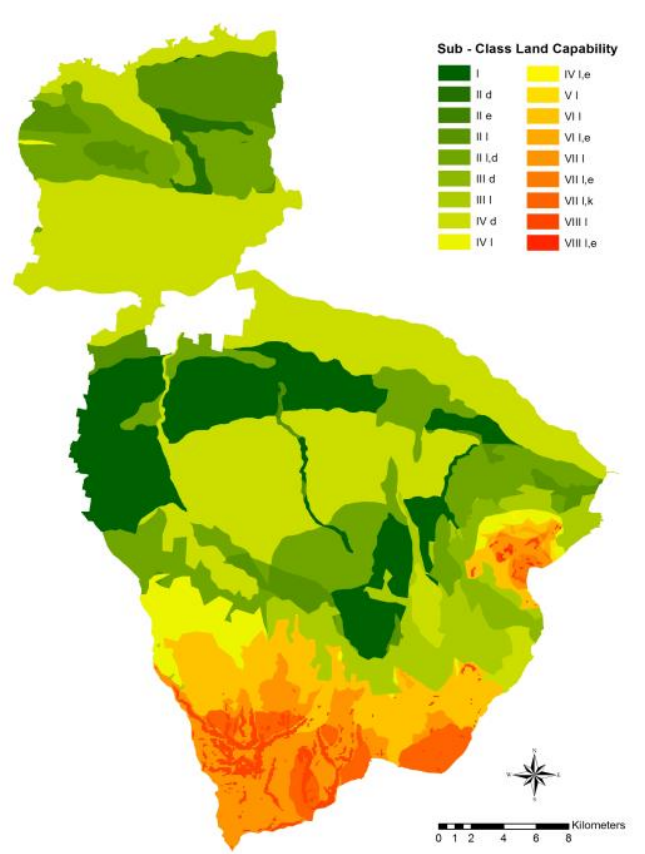

Figure 2. Land Capability Sub-Class in Mojokerto Regency.
Class I land has drainage that are good to rather good, with flat slope, medium and fine soil texture, effective depth tends to deep and no erosion.

Class II land that has land characteristics is almost the same as class I occupying an area of 22700.25 ha or $23.31 \%$, with fine to medium texture, effective depth in and class II land having the main barrier, rather poor drainage, with slope $11-15 \%$ and there is mild erosion. Land Class II is spread in Dawarblandong, Jetis, Jatirejo, Gondang, Ngoro, Kemlagi, Puri, Sooko, Mojosari, Trawas, Dlanggu and Kutorejo Districts.

Land class III capability in Mojokerto Regency occupies an area of $7767.64 \mathrm{Ha}$ or $7.98 \%$. The characteristics of the land are smooth to moderate textures, mild erosion, effective depth inside and have a main barrier which has rather good drainage to rather fast and the slope of the slope is rather tilted (11-15\%) to tilt (15-30\%). This land class in Mojokerto Regency is in Trawas, Ngoro, Jetis, Pacet and Pungging Districts. 
Land class IV dominating Mojokerto Regency occupies an area of $35,776.32$ hectares or $36.73 \%$. The land of this class has characteristics of the soil with fine to medium textures, the effective depth of the soil to medium and has the main limitation in the form of obstructed drainage (bad to very bad), with a sloping slope (15-30\%) to rather steep (30-45\%) and medium erosion. This land class is in Trawas, Pacet, Jatirejo, Dlanggu, Puri, Sooko, Kutorejo, Bangsal, Pungging, Mojosari, Mojoanyar, Ngoro, Kemlagi, Jetis Gedek, and Dawarblandong.

Table 3. Land Capability Class in Mojokerto Regency

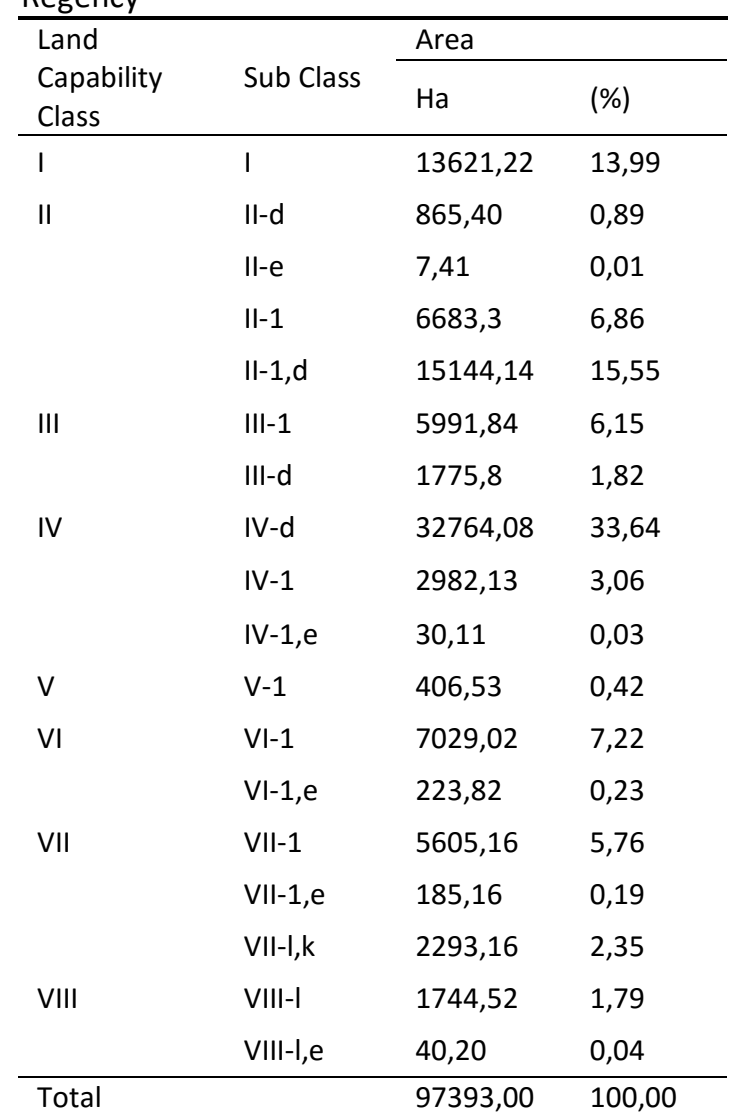

Explanation:

(-) reduced; (+) increased

Land class $\mathrm{V}$ and class $\mathrm{VI}$ is land that almost has the same characteristics. In class $\mathrm{V}$ land occupies an area of $406.53 \mathrm{Ha}$ or $0.42 \%$, with the characteristics of the land being medium textured, no erosion, the effective depth tends to be deep, well drained and has a main barrier dominated by rather steep slope (30-45\%) and steep (45-65\%). Class V in Mojokerto Regency can be found in Ngoro District. While land VI occupies an area of $7,252.84$ ha or $7.45 \%$, the characteristics of the land are drained well to rather good, fine and medium textured, effective depth tends to be deep and has a main barrier in the form of steep slopes (45-65\%) and moderate to erosion weight. This land can be found in Ngoro, Jatorejo, Pacet, Trawas and Gondang Districts.

In land class VII in Mojokerto Regency occupies an area of 1784.71 ha or $1.83 \%$, with characteristics of fine and medium-textured land, well drained and has a main limitation in the form of steep slopes (45-65\%) and medium to shallow effective depths and moderate to severe erosion. This class can be found in Ngoro, Jatirejo, Gondang, Pacet and Trawas Districts. Furthermore, the land included in the class VIII category, class VIII land occupies an area of 1784.71 ha or $1.83 \%$ with characteristics of fine and medium-textured land, well drained, effective depth to shallow depth and has a main barrier in the form of very steep slopes (>65\%) and erosion from severe to very heavy. This class of land in Mojokerto Regency can be found in Ngoro, Jatirejo, Gondang and Trawas Districts.

\section{Evaluation of Suitability Actual Land Use}

The actual land use in Mojokerto Regency as a result of analysis of Landsat $8 \mathrm{OLI}$ images is shown in Table 4 and Figure 3. In terms of area, actual land use is dominated by agricultural land and settlements.

Table 4. Actual Land Use in Mojokerto Regency

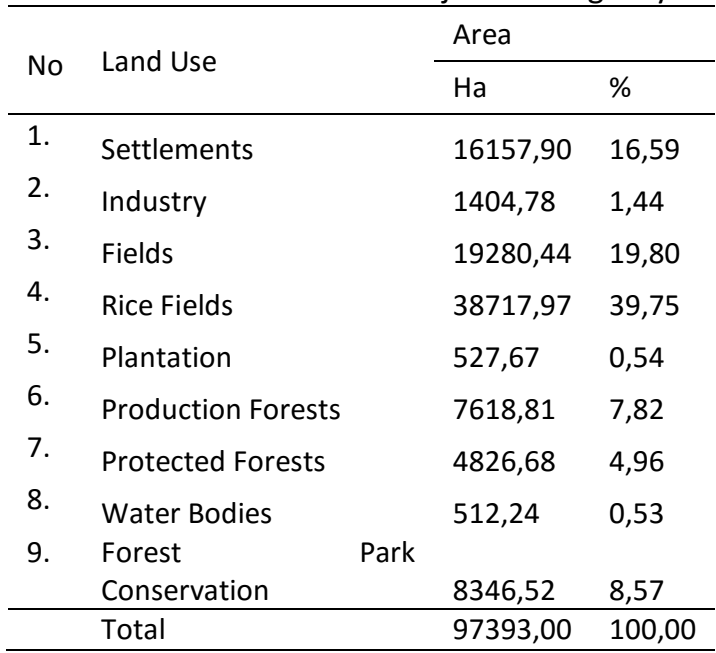

Source: Analysis Result of Landsat 8 OLI TIRS, Mei 7, 2018

Land use in Mojokerto Regency is currently in accordance with the capability of the land, reaching 95314.33 ha or $98 \%$, while the land that is not suitable is 2078.67 ha or only $2 \%$. The 
description of the actual land use data that is not in accordance with the land capability is presented in Table 5 and Figure 4. The actual land use included in the Class I category has all been allocated according to the land capability [40];[41].

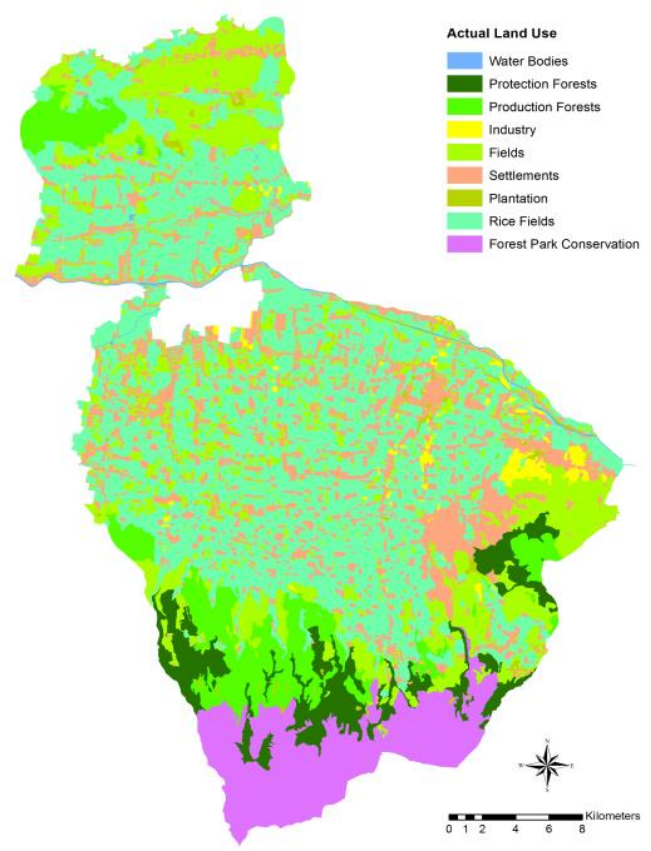

Figure 3. Actual Land Use in Mojokerto Regency

In Class II land there are 6.31 ha of land that is not suitable for industrial use, rice fields and fields. While class III land with an area of 51.57 ha there is use of paddy fields and fields that are not in accordance with the capabilities of the land. And in class IV land that is not suitable land area of 215.08 ha is intended for settlements, fields, fields and plantations [42]. Actual land use on class II-IV land is influenced by inhibiting factors that limit the ability of the land to include slopes that are sloping to a rather steep, erosion to poor drainage. So it is not recommended to manage agricultural land on land with a rather steep slope to sloping because it can cause landslides and floods [43].

Class $\mathrm{V}$ land included in the inappropriate category is land designated as settlement and fields of 40.29 ha. Class VI area of 1166.94 ha There are no suitable land designated as settlements, fields, fields and plantations. Next class VII land was found to be non-compliant land covering an area of 496.9 ha, namely land designated as rice field settlements, fields and plantations [44]. While class VIII with an area of $101.58 \mathrm{Ha}$ has been used not suitable for settlements, fields, plantations and production forests. Actual land use on class V to VIII land is land that has a rather steep to steep slope so that the land in this class is not suitable as cultivation land, especially class VIII land the slope is very steep (> 65\%) then the land is only suitable as protected forests and nature reserves.

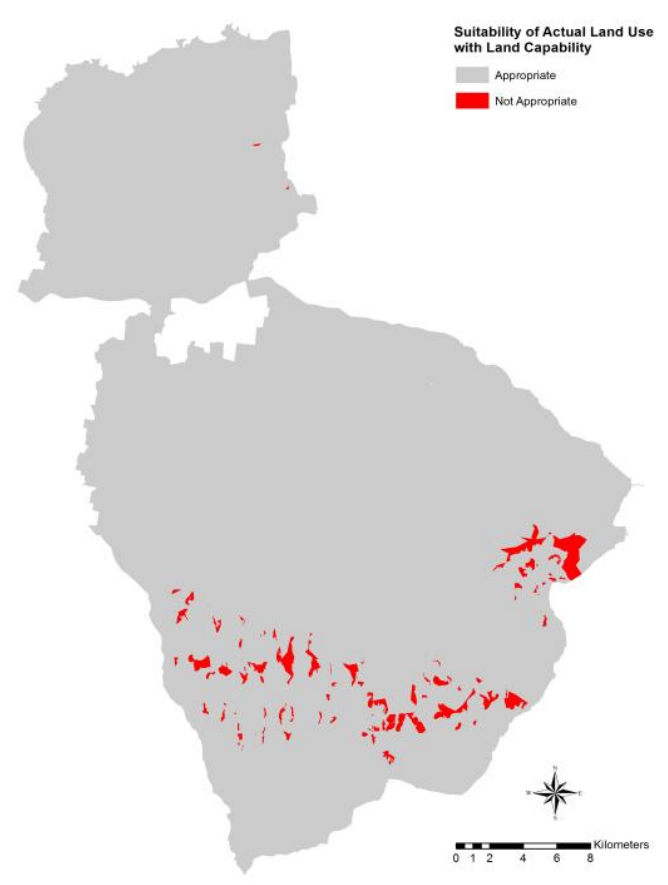

Figure 4. Suitability of Actual Land Use and Land Capability in Mojokerto Regency

Evaluation of Land Allocation in the Spatial Plan

The allocation of land space in Mojokerto Regency Spatial Plan (MRSP) is shown in Figure 5. The results of the suitability analysis between land capability and MRSP are presented in Table 6 and Figure 6, indicating that land with high to moderate capability in Mojokerto Regency (class I-IV) is 60280.32 ha have been allocated for land use that is suitable for their capabilities. The land area of 18884.18 ha in the MRSP allocation exceeds the carrying capacity of the land, but can still be used conditionally, and is found to be only an area of 17.61 ha or $0.02 \%$ of land for which allocation is not appropriate.

Allocation of land in the Mojokerto Spatial Plan whose designation is still conditionally appropriate requires conservation measures to make land use more optimal. In land settlements already built which is influenced by the slope to the bumpy slope boundaries, can be made good water canal and planting erosion-resistant vegetation in the yard, while on settlements land 
will be built, land leveling can be carried out by landfilling or compaction.

Table 5. Actual Land Capability Classes in Mojokerto Regency

\begin{tabular}{|c|c|c|c|c|c|c|c|c|c|}
\hline \multirow{2}{*}{ Land Use } & \multicolumn{8}{|c|}{ Area of Land Capability Class (Ha) } & \multirow{2}{*}{ Total } \\
\hline & I & II & III & IV & $\mathrm{V}$ & VI & VII & VIII & \\
\hline Settlements & & & & 6,09 & 3,19 & 91,81 & 354,93 & 0,02 & 456,04 \\
\hline Industry & & 0,08 & & & & & & & 0,08 \\
\hline Rice Fields & & 1,98 & 49,55 & 113,64 & & 214,78 & 5,95 & & 405,90 \\
\hline Fields & & 4,25 & 2,02 & 70,57 & 37,10 & 798,69 & 95,30 & 5,11 & 1013,04 \\
\hline Plantation & & & & 4,78 & & 61,66 & 40,72 & 1,96 & 109,12 \\
\hline Production Forests & & & & & & & & 94,49 & 94,49 \\
\hline Total & - & 6,31 & 51,57 & 215,08 & 40,29 & 1166,94 & 496,90 & 101,58 & 2078,67 \\
\hline
\end{tabular}

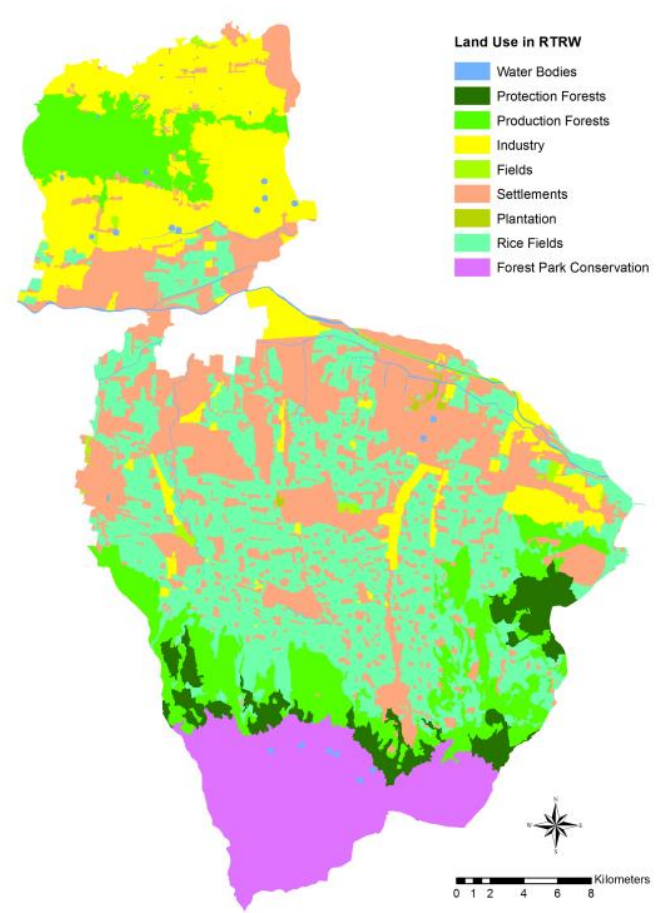

Figure 5. Land use in Mojokerto Regency.

Furthermore, on agricultural land which is limited by slopes and drainage can be overcome by making guludan or changing cropping patterns so that the soil is not saturated and cause erosion and need to repair drainage channels so that when the rainy season is not flooded and when the dry season does not occur water shortages.

Compared to class I-IV land, the land that is not suitable for land with capabilities that are rather low to low (class $\mathrm{V}$ to class VIII) is higher. Land whose allocation does not match or exceed the capacity of the land is 817.02 hectares or

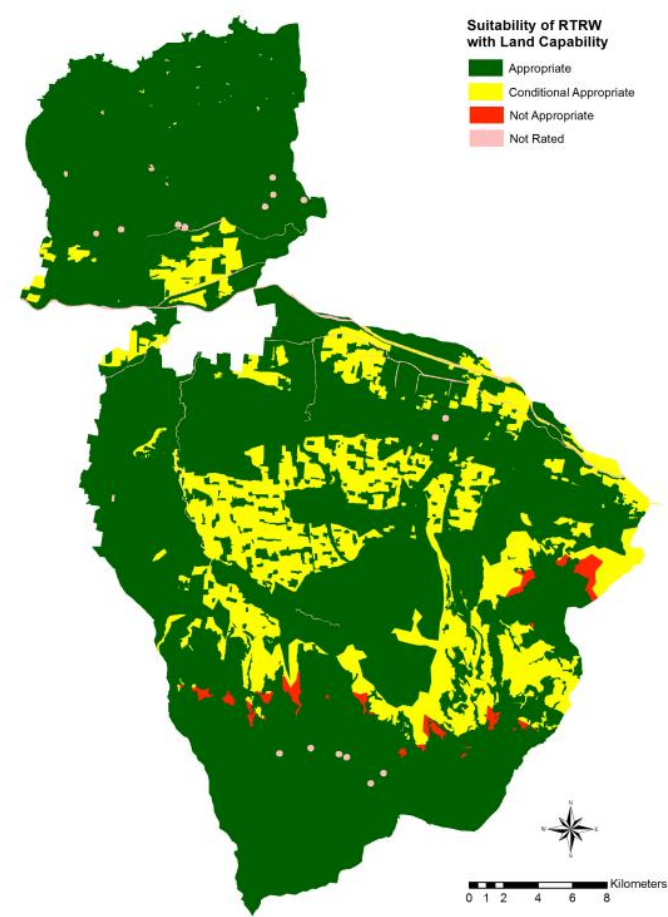

Figure 6. Land Capability distribution in Mojokerto Regency

$4.71 \%$ of the total area, while the land that has been allocated is 16518.57 hectares or $95.29 \%$.

The lower capability of land are more suitable for use as grazing or forest land, especially the Class VIII of land-capability which has the very steep slope only suitable for the nature reserve area (protection areas). The quality of Mojokerto Spatial Plan (MRSP) is still good, however it should be seriously noted the land allocation in the future, especially for parts of the region where the land allocation beyond their carrying capacity. 
Evaluation of Land Use Suitabililty (Firdaus, et al.)

Table 6. Suitability in each of Land Capability classes in Mojokerto Regency

\begin{tabular}{|c|c|c|c|c|c|c|c|c|c|c|}
\hline \multirow{2}{*}{ RTRW } & \multirow{2}{*}{ Suitability } & \multicolumn{8}{|c|}{ Area of Land Capability Class (Ha) } & \multirow{2}{*}{ Total } \\
\hline & & $\mathbf{I}$ & II & III & IV & $\mathbf{v}$ & VI & VII & VIII & \\
\hline \multirow{3}{*}{ Settlements } & Appropriate & 5534.62 & 5001,75 & 234,06 & 11807.51 & - & - & - & - & 22577.94 \\
\hline & $\begin{array}{l}\text { Conditional } \\
\text { Appropriate }\end{array}$ & - & $283,67(s)$ & 946,98 (s) & $90,72(\mathrm{~s})$ & - & - & - & - & 1321,36 \\
\hline & Not Appropriate & - & - & - & - & $\begin{array}{l}12,56 \\
(\mathrm{~s}, \mathrm{e})\end{array}$ & $196,07(s, e)$ & $18,15(s, e)$ & $5.35(\mathrm{~s}, \mathrm{e})$ & 232,13 \\
\hline \multirow[b]{2}{*}{ Industry } & Appropriate & 542.52 & 6713,57 & 14,74 & 8036.86 & - & - & - & - & 15307,70 \\
\hline & $\begin{array}{l}\text { Conditional } \\
\text { Appropriate }\end{array}$ & - & $11,09(\mathrm{~s})$ & $43,01(s)$ & - & - & - & - & - & 54,10 \\
\hline \multirow{3}{*}{ Rice Fields } & Appropriate & 6987,60 & 6091,25 & - & - & - & - & - & - & 13078.80 \\
\hline & $\begin{array}{l}\text { Conditional } \\
\text { Appropriate }\end{array}$ & - & $\begin{array}{l}710,17 \\
(s, d)\end{array}$ & $\begin{array}{l}3691,6 \\
\text { (d) }\end{array}$ & $\begin{array}{l}12889,9 \\
(s, d)\end{array}$ & - & - & - & - & 17291.70 \\
\hline & Not Appropriate & - & - & $0,97(s, e)$ & $16,64(\mathrm{~s}, \mathrm{e})$ & $27,06(s, e)$ & $528,13(\mathrm{~s}, \mathrm{e})$ & $6,22(s, e)$ & $5.14(\mathrm{~s}, \mathrm{e})$ & 584.16 \\
\hline \multirow[b]{2}{*}{ Fields } & Appropriate & 263.93 & 6.04 & - & 320.45 & - & - & - & - & 590.42 \\
\hline & $\begin{array}{l}\text { Conditional } \\
\text { Appropriate }\end{array}$ & - & $25.89(\mathrm{~s})$ & 1.12 (s) & $139.06(s, d)$ & - & - & - & - & 166.07 \\
\hline \multirow[b]{2}{*}{ Plantation } & Appropriate & - & 18.20 & - & 73.41 & - & - & - & - & 91.61 \\
\hline & $\begin{array}{l}\text { Conditional } \\
\text { Appropriate }\end{array}$ & - & $50.98(s)$ & $0.54(\mathrm{~s})$ & - & - & - & - & - & 50.98 \\
\hline \multirow{2}{*}{$\begin{array}{l}\text { Production } \\
\text { Forests }\end{array}$} & Appropriate & 265.55 & 3788.19 & 2482.28 & 1721.84 & - & 2098.15 & 93.27 & - & 10449.30 \\
\hline & Not Appropriate & - & - & - & - & - & - & - & $18.34(\mathrm{~s}, \mathrm{e})$ & 18.34 \\
\hline $\begin{array}{l}\text { Protected } \\
\text { Forests }\end{array}$ & Appropriate & - & - & 330.27 & 23.61 & 0.67 & 2187.55 & 730.32 & 136.97 & 3409.39 \\
\hline $\begin{array}{l}\text { Forest Park } \\
\text { Conservation }\end{array}$ & Appropriate & - & - & 22.07 & - & 238.45 & 2202.63 & 7217.35 & 1613.20 & 11293.70 \\
\hline Water Bodies & Not Assessed & 27.00 & 119.93 & - & 656.32 & 127.79 & 40.31 & 18.17 & 5.70 & 875.29 \\
\hline Total & & 13621.22 & 22700.25 & 7767.64 & 35776.32 & 406.53 & 7252.84 & 8083.48 & 1784.71 & 97393.00 \\
\hline
\end{tabular}

Explanation:

$(s, e, d)$ : land area limited by inhibitor such as slope, erotion and drainage. 
Any seriously efforts to improve the MRSP is very necessary based on socio-economics conditions of local communities [45];[46];[47];[48] [49].

\section{CONCLUSION}

The area of Mojokerto Regency has land with land capability classes varying from class I to class VIII. The majority of land has capabilities that can support agricultural businesses (class I to class IV), but there are other small parts that should not be used for cultivation (class V to class VIII). Factors that limit the ability of land include texture, effective depth, drainage, slope, and erosion rates. The actual land use in Mojokerto Regency includes Settlements; Rice fields; Field; Industry; Plantation; Production forest; Protected forest; Forest Park Conservation; and Water Body. Settlements and agricultural land are the most dominant land uses, followed by Forest Park, forests, industries and plantations.

Overall, most of the land in Mojokerto Regency has been used in accordance with the land capabilities, and it is found that little of the land used is inappropriate. While the spatial pattern in the Mojokerto Spatial Plan has allocated a large part of the land in accordance with the land capabilities. Nevertheless, there is still a small portion of the area whose allocation of land use exceeds the land capabilities.

The results of this study indicate that sufficient land conservation efforts are needed for lands that have actually been used inappropriate. This research can also be used as input for the improvement of the Regional Spatial Plan in the 5-year revision cycle so that the allocation of land in spatial planning is more appropriate with land capabilities.

\section{ACKNOWLEDGEMENT}

The researchers would like to thank the colleagues who helped the conducted of this research.

\section{REFERENCES}

[1]. Magsi,H., A. Torre, Y. Liu, M.J. Sheikh. 2017. Land use conflicts in developing countries; proximate driving forces and preventive measures Pak. Dev. Rev., 56 (1): 19-30.

[2]. Pawitan, H. 2014. Land Use Changes and Their Impacts on Watershed Hydrology. https://www.researchgate.net/publication/ 237486643.

[3]. Cardenas,D.C. 1996. Effects of land-use conversion on local agriculture: The case of
Cavite, Philippines. Journal of SocioEconomic Research, 10(1): 45-68.

[4]. Yansui,L., G.Hong, J.Gao and D.Xusheng. 2004. The causes and environmental effects of land use conversion during agricultural restructuring in Northeast China. Jour. of Geogr.Sci., 14(4): 488-494.

[5]. Agus,F. and D.Irawan. 2006. Agricultural land conversion as a threat to food security and environmental quality. Journal Litbang Pertanian, 25(3): 90-98.

[6]. Minale, A.S. 2013. Retrospective analysis of land cover and use dynamics in Gilgel Abbay Watershed by using GIS and remote sensing techniques, Northwestern Ethiopia. Int. J. Geosci., 4(07): 1003

[7]. Naab,F.Z., R.D. Dinye, and R.K. Kasanga. 2013. Urbanization and its impact on agricultural lands in growing cities in developing countries: a case study of tamale in Ghana. Mod. Soc. Sci. J., 2: 256-287.

[8]. Nguyen,T.H.T., V.T.Tran, Q.T.Bui, Q.H.Man, and T.deV.Walter. 2016. Socio-economic effects of agricultural land conversion for urban development: Case study of Hanoi, Vietnam. Land Use Policy, 54: 583-592.

[9]. Ustaoglu,E., C.P.Castillo, C. Jacobs-Crisioni, and C. Lavalle. 2016. Economic evaluation of agricultural land to assess land use changes. Land Use Policy, 56: 125-146.

[10]. Departement of Agriculture, Mojokerto Regency. 2018. Land Use Report 2013-2017. Mojokerto: Departement of Agriculture, Mojokerto Regency.

[11]. Liu,J.Y., X.Z.Deng, and M.L.Liu. 2002. Study on the spatial patterns of land-use change and analyses of driving forces in northeastern China during 1990-2000. Chinese Geographical Science, 12(4): 299308.

[12]. Polasky,S., Nelson,E., Pennington, D., and Johnson, K.A., 2011. The impact of land-use change on ecosystem services, biodiversity and returns to landowners: a case study in the state of minnesota. Environ. Resour. Econ., 48: 219-242.

[13]. Quasem,A. 2011. Conversion of agricultural land to non-agricultural uses in Bangladesh: Extent and determinants. Bangladesh Journal of Development Studies, 34(11): 6082.

[14]. Lawler,J., Lewis, D., Nelson, E., Plantinga, A.J., Polasky, S., Withey, J., Helmers, D., Martinuzzi, S., Radeloff, V., 2014. Projected land-use change impacts on ecosystem 
services in the U.S. Proc. Natl. Acad. Sci., 111(20): 7492-7497.

[15]. Wang,G., Y. Liu, Y. Li and Y. Chen. 2015. Dynamic trends and driving forces of land use intensification of cultivated land in China. J. Geog. Sci., 25 (1): 45-57.

[16]. Carrión-Flores,C. and E.G.Irwin. 2004. Determinants of residential land use conversion and sprawl at the rural-urban fringe. American Journal of Agricultural Economics,86(4), 889-904.

[17]. Singer, M.J., 2014. Land Capability Analysis. In Encyclopedia of Natural Resources: Land. Taylor and Francis, New York. 295-298.

[18]. Dempseya,J.A., A.J.Plantinga, J.D.Kline, J.J. Lawler, S.Martinuzzi, V.C.Radeloff and D.P.Bigelow. 2017. Effects of local land-use planning on development and disturbance in riparian areas. Land Use Policy, 60: 1625.

[19]. Beckmann,V.T., L.Van den Berg, and F.Qu. 2009. Governing farmland conversion: Comparing China with Netherlands and Germany. Land Use Policy, 26(2): 961-974.

[20]. Firman,T. 2010. Land conversion and urban development in Northern region of West Java of Indonesia. Journal of Urban Studies, 34: 1027-1046.

[21]. Faradina, Renanda,A., Bambang,R., dan Bambang,S. 2015. Analysis Land Capability Class as Determinants of Land Use Suitability in Sidoarjo. Jurnal Sumberdaya Alam dan Lingkungan Brawijaya, 2(2): xx.

[22]. Rondhi,M., P.A.Pratiwi , V.T.Handini , A.F.Sunartomo and S.A.Budiman. 2018. Agricultural Land Conversion, Land Economic Value, and Sustainable Agriculture: A Case Study in East Java, Indonesia. Land, 7, 148, 19p.

[23]. Doran,J.W. 2002. Soil health and global sustainability: translating science into practice. Agriculture, Ecosystems \& Environment, 88(2): 119-127.

[24]. Bouma,J. 2002. Land quality indicators of sustainable land management across scales. Agriculture, Ecosystems \& Environment, 88(2): 129-136.

[25]. Choudhury,M.R and Das. S. 2015. An Integrated Geo-Spatial Studies for Land Capability Assessment of Agricultural Field Especially for Paddy Cultivation. Asian Journal of Geoinformatics, 15 (2): xx.

[26]. Nyanga,A., A.Kessler and A.Tenge. 2016. Key socio-economic factors influencing sustainable land management investments in the West Usambara Highlands, Tanzania. Land Use Policy, 51: 260-266

[27]. Mondal, M and Mondal. Md. A. 2015. Land Capability Classification of Purba Medinipur district, W.B.: A Geographical Case study. International Research Journal of Earth Sciences, 3(9): xx.

[28]. Herrick,J.E. 2000. Soil quality: an indicator of sustainable land management? Applied Soil Ecology, 15(1): 75-83.

[29]. Weiland,U., A. Kindler, E.Banzhaf, A.Ebert and S.Reyes-Paecke. 2011. Indicators for sustainable land use management in Santiago de Chile. Ecological Indicators, 11(5): 1074-1083.

[30]. Mirzabaev,A., E.Nkonya, and J.Braun. 2015. Economics of sustainable land management. Current Opinion in Environmental Sustainability, 15: 9-19.

[31]. de Obade,V.P. and R.Lal. 2016. A standardized soil quality index for diverse field conditions. Science of The Total Environment, 541: 424-434.

[32]. Nigussie,Z., A.Tsunekawa,N.Haregeweyn, E.Adgo, M.Nohmi, M.Tsubo, D.Aklog, D.T.Meshesha and S.Abele. 2017. Factors influencing small-scale farmers' adoption of sustainable land management technologies in north-western Ethiopia. Land Use Policy, 67: 57-64

[33]. Elwood, S. and H. Lietner. 1998. GIS and Community-based Planning: Exploring the Diversity of Neighborhood Perspectives and Needs. Cartography and Geographic Information Systems, 25(2): 77-88.

[34]. Wegener, M. 1998. GIS and Spatial Planning. Environment and Planning B: Urban Analytics and City Science, 25(7): 48-52

[35]. Elwood, S. A. 2002. GIS use in community planning: a multidimensional analysis of empowerment. Environmental and Planning A, 34(5): 905-922.

[36]. Widiatmaka, W, M. Yanuar J.P., Yudi S. dan Hefni E. 2015. Land Capability Based Environmental Carrying Capacity in Tuban, East Java. Jurnal Manusia Dan Lingkungan, 22(2): 247-259.

[37]. Cdai,F., C.F.Lee and X.Hzhang. 2001. GISbased geo-environmental evaluation for urban land-use planning: a case study.Engineering Geology, 61(4): 257-271.

[38]. Schädler, S., Finkel, M., Bleicher, A., Morio, M. and Gross,M. 2013. Spatially explicit computation of sustainability indicator values for the automated assessment of 
land-use options. Landscape and Urban Planning, 111: 34-45.

[39]. Fenton,T.E. 2014. Land Capability Classification. In Encyclopedia of Natural Resources: Land. Taylor and Francis: New York. Pp.299-301.

[40]. Hurni,H., M.Giger, H.Liniger, R.M.Studer, P.Messerli, B.Portner, G.Schwilch, B.Wolfgra $\mathrm{mm}, \mathrm{T}$.Breu. 2015. Soils, agriculture and food security: the interplay between ecosystem functioning and human wellbeing. Current Opinion in Environmental Sustainability, 15: 25-34.

[41]. Aragon,N.U., M.Wagner, M.Wang, A. M. Broadbent, N. Parker and M.Georgescu. 2017. Sustainable Land Management for Bioenergy Crops. Energy Procedia, 125: 379388.

[42]. He,C., Q.Han, B.de Vries, X.Wang, and Z.Guochao. 2017. Evaluation of sustainable land management in urban area: A case study of Shanghai, China. Ecological Indicators, 80: 106-113

[43]. Doran,J.W. and M.R.Zeiss. 2000. Soil health and sustainability: managing the biotic component of soil quality. Applied Soil Ecology, 15(1): 3-11.

[44]. Emerton,L. and K.A.Snyder. 2018. Rethinking sustainable land management planning: Understanding the social and economic drivers of farmer decision-making in Africa. Land Use Policy, 79: 684-694.

[45]. Haque,A. and Y.Asami. 2011. Optimizing Urban Land-Use Allocation: Case Study of Dhanmondi Residential Area, Dhaka, Bangladesh. Environment and Planning B: Urban Analytics and City Science, 38(3): 388-410.

[46]. Kim,J.H. 2011. Linking Land Use Planning and Regulation to Economic Development: A Literature Review. Journal of Planing Literature, 26(1): 35-47.

[47]. Curran-Cournane,F., M.Vaughan, A.Memon and C.Fredrickson. 2014. Trade-offs between high class land and development: Recent and future pressures on Auckland's valuable soil resources. Land Use Policy, 39: 146-154.

[48]. Fuseini,I. and J.Kemp. 2015. A review of spatial planning in Ghana's socio-economic development trajectory: A sustainable development perspective. Land Use Policy, 47: 309-320.

[49]. Abass,K., S.K.Adanu and S. Agyemang. 2018. Peri-urbanisation and loss of arable land in
Kumasi Metropolis in three decades: Evidence from remote sensing image analysis. Land Use Policy, 72: 470-479. 